\title{
MdMADS2 - transgenic chrysanthemum (Dendranthema grandiflorum (Ramat.) Kitamura) showing the reduction of the days to flowering
}

\author{
Bong-Hee Han $\cdot$ Su Young Lee $\cdot$ Seong Youl Choi
}

Received: 10 August 2009 / Accepted: 17 December 2009

(c) Korean Society for Plant Biotechnology

\begin{abstract}
This study was conducted to develop new lines expressing the characteristic of early flowering by introducing MdMADS2 gene in chrysanthemum (Dendranthema grandiflorum (Ramat.) Kitamura) 'Zinba'. Transformation of chrysanthemum was conducted by Agrobacterium tumefaciens LBA4404 harboring the binary vector containing MdMADS2 controlled by double CaMV $35 \mathrm{~S}$ promoters. Ninety three shoots were regenerated from 1,463 leaf segment explants cultured on the first selection medium (MS basal salts +1.0 $\mathrm{mg} / \mathrm{L} \mathrm{BA}+0.5 \mathrm{mg} / \mathrm{L} \mathrm{IAA}+10 \mathrm{mg} / \mathrm{L}$ kanamycin $+400 \mathrm{mg} / \mathrm{L}$ cefotaxime, $\mathrm{pH}$ 5.8) after co-cultivation, and 20 out of the 93 shoots rooted on the second selection medium containing 20 $\mathrm{mg} / \mathrm{L}$ kanamycin and $400 \mathrm{mg} / \mathrm{L}$ cefotaxime. Many escapes (98.6\%) were removed on the selection stage for rooting. Nineteen lines were confirmed as transgenic plant with transgene by PCR analysis. Six transgenic plants flowered 2-11 days earlier than non-transgenic plant without big change of phenotype, and especially, 3 (Mo-7, Mo-11, Mo-17) out of 6 transgenic lines showed a significant reduction in days to flowering compared to non-transgenic plant. Introduction and expression of MdMADS2 gene in them were confirmed by Southern and real-time PCR analyses, respectively.
\end{abstract}

Keywords Agrobacterium tumefaciens, Kanamycin, MdMADS2, rooting selection, transformation

\section{Introduction}

Chrysanthemum (Dendranthema grandiflorum (Ramat.) Kitamura) is one of the major cut flowers in the world, and its many characteristics have been improved through conven-

B.-H. Han · S.-Y. Lee $(\bowtie) \cdot$ S.-Y. Choi

(Floriculture Research Division, National Institute of

Horticultural \& Herbal Science, 540-41 Tap-dong,

Gwonseon-gu, Suwon, 441-440, Korea)

e-mail: 1sy8542224@korea.kr tional breeding methods. Recently, the molecular transformation technique has an alternative approach to improve specific characteristics of chrysanthemum making use of its advantage as 'one point' crop improvement (Ledger et al. 1991; Han et al. 2003; Han et al. 2007 Khodakovskaya and Vaňková 2009; Tong et al. 2009). In addition, because chrysanthemum is propagated mainly by cutting and suckering, any desirable lines obtained through transformation can be easily developed as useful cultivars (Aswath et al. 2004).

The life cycle of chrysanthemum is very important for year round cut flower production. In the Netherlands, flowers of chrysanthemum are harvested 3.5 to 4 times a year, whereas only two times in Korea due to environmental and cultural restricting factors found in greenhouse such as propagation of plantlets, temperature extremes during summer and winter, and long life cycle. Therefore, the shortening of its life cycle is needed to increase the number of its harvesting in a year (Han et al. 2003).

Flower formation in higher plants is a complex process controlled by genetic and environmental factors (Bernier 1988; Yanofsky 1995; Amasino 1996; Levy and Dean 1998). Much has been learned from genetic and molecular studies of floral meristem and floral organ formation in Arabidopsis and Snapdragon (Sung et al. 1999). It has been known that MADS-box genes are important regulators of meristem and floral organ identity. Recent research demonstrated that MADS-box genes in Arabidopsis are important regulators of meristem and floral organ identity as well as flowering timing and cell-type specification in floral organs (Jack 2002). MdMADS2, which shows high sequence similarities to the SQUAMOSA subfamily genes isolated from Fuji apple, was introduced in tobacco. The transgenic tobacco expressing the MdMADS2 gene from the CaMV 35S promoter showed early flowering and shorter bolts without any homeotic changes in the floral organs (Sung et al. 1999). These results suggest that MdMADS2 plays an important role during early stages of flower development. 
Based on this information, this study was conducted to develop new lines showing the reduction of its life cycle through expressing the characteristic of early flowering by introducing $M d M A D S 2$ gene into chrysanthemum cv. Zinba, which has a big white flower as a standard cut flower cultivar, has been cultivated in most parts of Korea since 2000 because of its vigorous growth, and has late flowering time and long life cycle flowering.

\section{Materials and methods}

Plant material

Chrysanthemum cv. Zinba applicable for improving a characteristics using genetic transformation technique was used as plant material because of its high regeneration ability (Han et al. 2009). Young shoots were taken from the mother plants growing in green house at National Institute of Horticultural $\&$ Herbal Science (NIHHS), and the surface of the shoots was sterilized with $70 \%$ ethyl alcohol for $30 \mathrm{~s}$ and $1.0 \%$ sodium hypochlorite for $15 \mathrm{~min}$, and then rinsed three times with sterilized water. The shoots were incubated on MS basal medium (Murashige and Skoog 1962) and subcultured at eight-week intervals.

Agrobacterium-mediated transformation

MdMADS2 gene (NCBI No. U78948), which was cloned from apple (Malus $\times$ domestica) and subcloned into pCAMBIA 2301 (containing double CaMV 35S promoter digested with NcoI and EcoRI) by Soon-Kee Sung in Dongbu Technology Institute, was used (Fig. 1). The whole process of Agrobacterium-mediated transformation from co-cultivation to the first selection was conducted as described by Han et al. (2007). A number of studies reported that chrysanthemum is very susceptible to kanamycin (the lethal concentrations are 10-50 $\mathrm{mg} / \mathrm{L}$ depending on the cultivars), and many 'escape' (nontransgenic) shoots were obtained through transformation process (Ledger et al. 1991; Lowe et al. 1993; Renou et al. 1993; De Jong et al. 1994; Urban et al. 1994; Fukai et al. 1995 Taka- tsu et al. 1998). Due to this sensitivity to kanamycin of chrysanthemum, we performed the two-stage selection. At first, we let shoots from leaf explants regenerated on shoot regeneration medium containing $1.0 \mathrm{mg} / \mathrm{L} \mathrm{BA}, 0.5 \mathrm{mg} / \mathrm{L} \mathrm{IAA}, 10$ $\mathrm{mg} / \mathrm{L}$ kanamycin and $400 \mathrm{mg} / \mathrm{L}$ cefotaxime. And then, we let the regenerated shoots rooted on rooting selection medium (hormone-free MS medium, the second selection medium) containing $20 \mathrm{mg} / \mathrm{L}$ kanamycin and $400 \mathrm{mg} / \mathrm{L}$ cefotaxime. After the four weeks culture inthe second selection medium, the rooted plantlets were selected for PCR analysis and continuously maintained on MS medium containing $2 \mathrm{~g} / \mathrm{L}$ activated charcoal as putative transformants.

\section{PCR analysis}

Putative transgenic plantlets, which regenerated in the first selection medium and rooted in the second selection medium, respectively, were subjected to PCR analysis. Genomic DNA was isolated from leaves of in vitro-grown plantlets according to the manufacturer's instructions of the DNeasy Plant Mini Kit (Qiagen, Germany). PCR was conducted using both neomycin phosphotransferase II ( $n p t \mathrm{II})$ gene specific primers (Han et al. 2007) and transgene specific primers (forward 5'-AAG GGT GCA GCT GAA GAG AA-3', and reverse 5'-TGG AGT TGG GGT TTC ATC TC-3'). The reaction mixture composition and amplification condition for nptII gene PCR were conducted as described by Han et al. (2007). The reaction mixture of MdMADS2 transgene PCR was composed of $5 \mu \mathrm{L}$ of extracted DNA, 10 pmol each of the forward and reverse primers, and $45 \mu \mathrm{L}$ of Platinum Blue PCR Super Mix (Invitrogen, USA). The amplification was carried out with 35 cycles of $30 \mathrm{~s}$ at $98^{\circ} \mathrm{C}, 1 \mathrm{~min}$ at $58^{\circ} \mathrm{C}, 1 \mathrm{~min}$ at 72 ${ }^{\circ} \mathrm{C}$ in an automatic thermal cycler (iCycler, Bio-Rad, USA).

Investigation of early flowering trait in transgenic chrysanthemum

The transgenic lines confirmed by PCR analysis, and nontransgenic plant (for control) were propagated on basal MS medium. Six plants per line were acclimatized on the cultural medium mixed with perlite and vermiculite in the ratio of $1: 1$

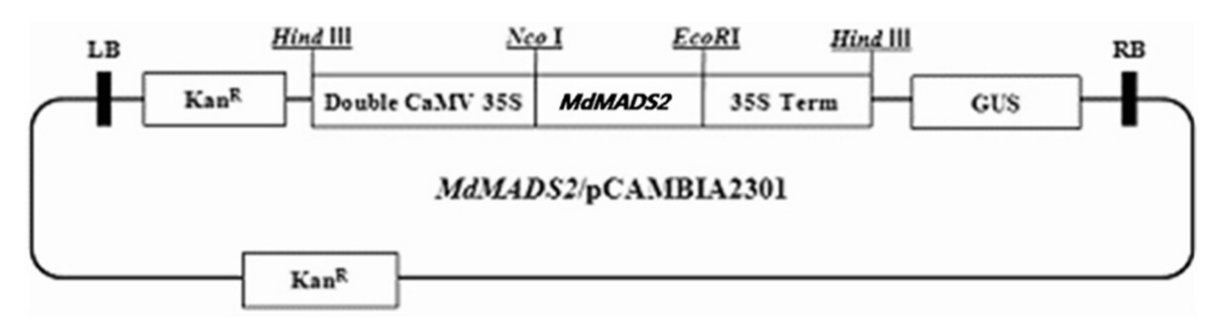

Fig. 1 A map of pCAMBIA 2301 with MdMADS2 gene used for plant transformation in this study 
in green house and treated with cold temperature $\left(5^{\circ} \mathrm{C}\right)$ in cold room for 1 month. The cuttings excised from each line were planted into the pots $(30 \mathrm{~cm}$ in diameter) in green house on July 2, 2008 after rooting. The trial included 3 replicates of pots per line. The characteristic of early flowering in the transgenic lines was investigated whenever the transgenic lines flowered.

\section{Southern analysis}

Southern blot analysis was performed on 6 transgenic lines showing the trait of early flowering. Genomic DNA was isolated from their leaves grown in greenhouse by using the CT AB method (Doyle and Dickson 1987). Twenty mg of DNA digested with $E c o R I$ was followed by electrophoresis on $1.0 \%$ agarose gel in TBE buffer ( $45 \mathrm{mM}$ Tris-borate, $45 \mathrm{mM}$ boric acid, 1 mMEDTA ( $\mathrm{pH} 8.0$ ) for $12 \mathrm{~h}$. Following electrophoresis, the DNA was transferred to Nylon Hybond ${ }^{\mathrm{TM}}-\mathrm{N}^{+}$ membrane (Amersham Life Science, UK). Hybridization was carried out with Church's buffer for $12 \mathrm{~h}$ at $65^{\circ} \mathrm{C}$ with $M d M A$ $D S 2$ gene specific probe labeled with $\left(\mathrm{a}-{ }^{32} \mathrm{P}\right) \mathrm{dCTP}$ by random primed labeling (Foster et al. 2002).

\section{Real-time qPCR}

Total RNA was isolated from $100 \mathrm{mg}$ leaves of 6 transgenic lines, respectively, and control with the RNeasy Plant Mini Kit (QIAGEN, Germany) according to the manufacturer's recommendations. A quality and concentration of the isolated RNA were done by gel electrophoresis (1\%, RNasefree) and spectrophotometry $(260 / 280 \mathrm{~nm})$. The two-step qPCR was performed. First strand cDNA synthesis was performed with $1 \mu \mathrm{g}$ of total RNA treated with DNase I (Promega, USA) using PrimeScript ${ }^{\mathrm{TM}}$ reverse transcription (RT) reagent kit (TAKARA, Japan) according to the supplier's recommendation. Primers were designed using the program primer 3 (Rozen and Skaletsky 2000). Sequence of MdMADS2 gene specific primers and chrysanthemum actin cDNA (GenBank accession No. AB205087) gene (used as a constitutive control gene) specific ones was as follows: forward of the one, 5'-GGGTGGAGGTTTTACAAAGAAA$3^{\prime}$; reverse of the one, $5^{\prime}$-TACTGCGTTCTCCTTCTCCTTC$3^{\prime}$; forward of the other, $5^{\prime}$-ACATGCTATCTTGCGTTTGG$3^{\prime}$; reverse of the other, $5^{\prime}$-CTCTCACAATTTCCCGTTCA-3'. The real-time PCR was carried out using the MJ OPTICON (BioRad, USA). The mixture ( $20 \mu \mathrm{L}$ final volumes) containing $10 \mu \mathrm{L}$ of a $2 \times$ SYBR Premix Ex TaqII (TAKARA, Japan), $2 \mu \mathrm{L}$ of primer-pair mix (primers concentration: 500/ $500 \mathrm{nM}$ ), and $2 \mu \mathrm{L} \mathrm{cDNA}$ first strand template was reacted with 40 cycles of $30 \mathrm{~s}$ at $95^{\circ} \mathrm{C}, 30 \mathrm{~s}$ at $58^{\circ} \mathrm{C}, 30 \mathrm{~s}$ at $72^{\circ} \mathrm{C}$ after $10 \mathrm{~min}$ at $95^{\circ} \mathrm{C}$ and following by a final step at $72^{\circ} \mathrm{C}$ for 10 min. Subsequently, melting curve was recorded between 65 and $95^{\circ} \mathrm{C}$ with the hold every $1 \mathrm{~s}$. The $2^{-\Delta \mathrm{Ct}}$ method (Livak and Schmittgen 2001) was used to calculate the relative expression of transgene. Each assay was repeated three times.

\section{Results and discussion}

\section{Agrobacterium-mediated transformation of MdMADS2}

A total of 1,463 leaf segments were co-cultivated with Agrobacterium tumefaciens LBA4404 harboring the binary vector pCAMBIA2301 containing the MdMADS2 gene. Shoot regeneration occurred on the edges of leaf segments. After 6 weeks culture on the first selection medium, 93 shoots from 1,463 leaf explants were regenerated. After that, when these greenish shoots were cultured in the second selection medium for 4 weeks in light condition, only 20 out of 93 shoots rooted in the second selection medium. From PCR analysis using $n p t I I$ gene-specific primers, the 20 rooted plantlets were confirmed to contain $n p t I I$ gene. However, from PCR analysis using MdMADS2 gene-specific primers, 19 out of them were confirmed to have transgene, whereas, 1 of them not to have transgene (Table 1, Fig. 2). As a result, 74 out of 93 regenerated on the $1^{\text {st }}$ selection medium were found as 'escape'. Seventy three (98.6\%) out of these 74 escapes was removed on the process of rooting selection medium with 20

Table 1 PCR analysis of shoots regenerated or plantlets rooted on the selection medium after co-cultivation with Agrobacterium tumefaciens LBA4404 harboring a binary vector pCAMBIA 2301 containing MdMADS2 gene in chrysanthemum (Dendranthema $\times$ grandiflorum (Ramat.) Kitamura) cv. Zinba

\begin{tabular}{ccccc}
\hline $\begin{array}{c}\text { No. of } \\
\text { explants }\end{array}$ & $\begin{array}{c}\text { No. of shoots } \\
\text { regenerated on the } \\
1^{\text {st }} \text { selection medium }\end{array}$ & $\begin{array}{c}\text { No. of shoots } \\
\text { rooted on the } 2^{\text {nd }} \\
\text { selection medium }\end{array}$ & $\begin{array}{c}\text { No. of transgenic } \\
\text { shoots with } \\
\text { nptII gene }\end{array}$ & $\begin{array}{c}\text { No. of transgenic } \\
\text { shoots with } \\
\text { MdMADS2 gene }\end{array}$ \\
\hline 1,463 & 93 & 20 & 20 & 19 \\
\hline
\end{tabular}

\footnotetext{
${ }^{\mathrm{z}} \mathrm{MS}$ medium was containing $1.0 \mathrm{mg} / \mathrm{L} \mathrm{BA}, 0.5 \mathrm{mg} / \mathrm{L} \mathrm{IAA}, 400 \mathrm{mg} / \mathrm{L}$ cefotaxime, and $10 \mathrm{mg} / \mathrm{L}$ kanamycin.

${ }^{\mathrm{y}} \mathrm{MS}$ medium was containing $400 \mathrm{mg} / \mathrm{L}$ cefotaxime, and $20 \mathrm{mg} / \mathrm{L}$ kanamycin.
} 


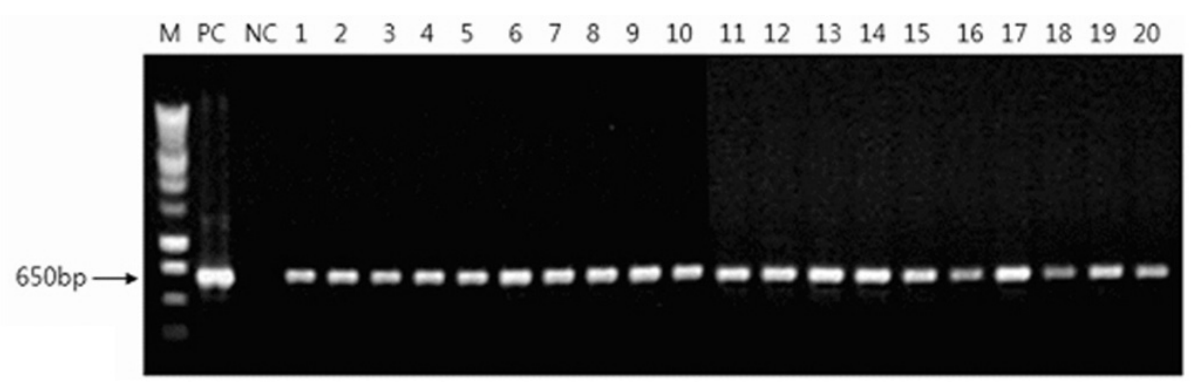

(a)

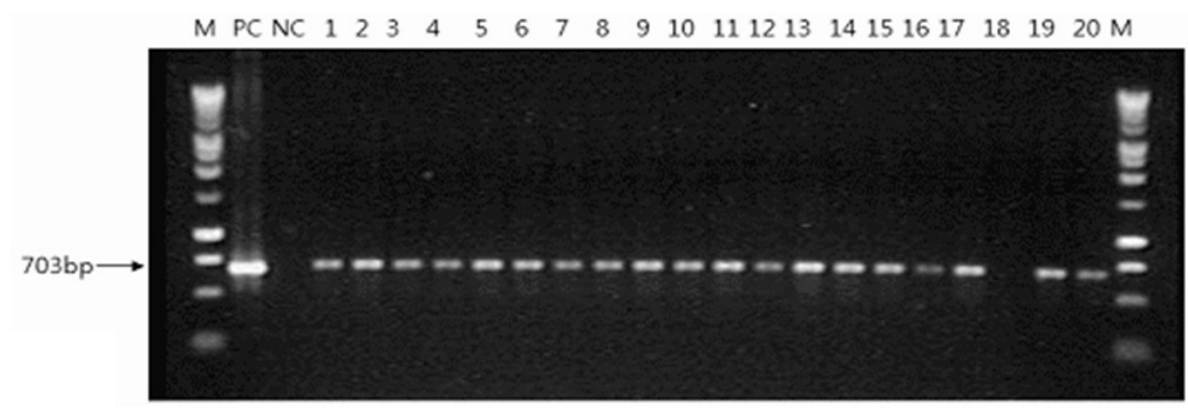

(b)

Fig. 2 PCR analysis of 20 pseudo-transgenic chrysanthemum plants rooted on the $2^{\text {nd }}$ selection medium after co-cultivation with Agrobacterium tumefaciens LBA4404 harboring a binary vector pCAMBIA 2301 containing MdMADS2 gene. PCR amplifications were performed with primers for $n p t I I$ (A) and MdMADS2 (B). M: molecular size(1 kb ladder), PC: pCAMBIA 2301 vector DNA, NC: non-transgenic plant, 1-20: putative transgenic plants

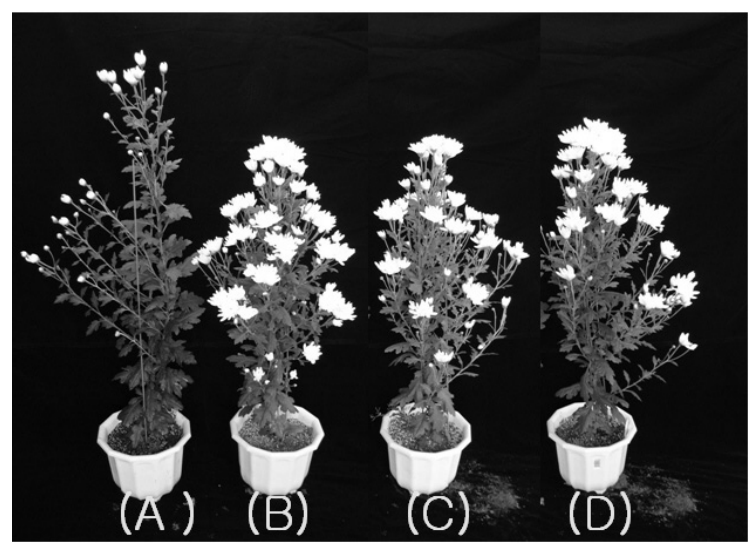

Fig. 3 MdMADS2-transgenic chrysanthemum lines showing earlyflowering. (A) non-transgenic plant. (B) (D) transgenic lines; (B) MO-7, (C) MO-11, (D) MO-17

$\mathrm{mg} / \mathrm{L}$ kanamycin. It could be said that this two-stage selection system, in which most of shoots regenerated without transgene in the first selection medium containing $10 \mathrm{mg} / \mathrm{L}$ kanamycin and $400 \mathrm{mg} / \mathrm{L}$ cefotaxime were not rooted on rooting medium containing $20 \mathrm{mg} / \mathrm{L}$ kanamycin and 400 $\mathrm{mg} / \mathrm{L}$ cefotaxime, was very desirable in removing escapes for genetic transformation of chrysanthemum. It is known that sensitivity to kanamycin varies depending on tissues. Root formation is generally more sensitive than shoot formation or callus growth (Draper et al. 1988). Saini et al.
(2003) reported that a second round of selection at the rooting stage was critical for transformation of Vigna mungo. The escape shoots from selection of regeneration stage were dramatically reduced by the rooting selection. The elimination of escapes by the rooting selection was reported in many studies (Boase et al. 1998; Yan and Wang 2007; Zou et al. 2008), too.

Field selection of MdMADS2 transgenic lines expressing traits of early flowering

Six out of 19 transgenic lines showed earlier flowering than non-transgenic plants (control). They flowered 2.3 to 11.3 days earlier than control, and three ones (MO-7, MO-11, and MO-17) (Fig. 3) appeared to have a significant reduction in days to flowering. They did not show differences in the number of branches on average compared to control. Whereas, their plant height was significantly reduced by about $30 \mathrm{~cm}$ at flowering time compared to control, and they showed a few differences in the number of nodes compared to the latter. The number of nodes of them was 3-7 fewer on average than that of control (Table 2). These results were the same as Sung et al. (1999)'report that let MdMADS2 gene introduced into tobacco. The several transgenic tobaccos showed to have shortened the number of flowering days by 8 to 10 days. At flowering time, the plant height of the transgenic tobaccos 
Table 2 Growth characteristics of 6 MdMADS2-transgenic lines from chrysanthemum (Dendranthema $\times$ grandiflorum (Ramat.) Kitamura) cv. Zinba

\begin{tabular}{lcccc}
\hline Lines $^{\mathrm{z}}$ & Plant height $(\mathrm{cm})$ & No of nodes & No of branches & Days to flowering \\
\hline Control & $95.3 \pm 3.5^{\mathrm{y}} \mathrm{a}^{\mathrm{x}}$ & $63.3 \pm 3.0 \mathrm{a}$ & $46.3 \pm 0.3 \mathrm{a}$ & $128.3 \pm 1.9 \mathrm{a}$ \\
MO-2 & $79.7 \pm 2.3 \mathrm{~cd}$ & $55.3 \pm 2.3 \mathrm{~b}$ & $43.0 \pm 2.9 \mathrm{a}$ & $126.0 \pm 0.6 \mathrm{a}$ \\
MO-7 & $73.3 \pm 1.8 \mathrm{~d}$ & $52.0 \pm 1.5 \mathrm{~b}$ & $39.0 \pm 2.1 \mathrm{a}$ & $117.0 \pm 0.6 \mathrm{c}$ \\
MO-11 & $78.3 \pm 1.8 \mathrm{~cd}$ & $57.7 \pm 0.9 \mathrm{ab}$ & $39.3 \pm 2.8 \mathrm{a}$ & $117.0 \pm 1.2 \mathrm{c}$ \\
MO-14 & $87.7 \pm 1.8 \mathrm{~b}$ & $57.3 \pm 2.3 \mathrm{ab}$ & $38.3 \pm 3.4 \mathrm{a}$ & $122.7 \pm 0.3 \mathrm{~b}$ \\
MO-17 & $76.3 \pm 2.2 \mathrm{~cd}$ & $55.7 \pm 2.0 \mathrm{~b}$ & $43.3 \pm 3.5 \mathrm{a}$ & $118.3 \pm 0.9 \mathrm{c}$ \\
MO-20 & $82.3 \pm 1.7 \mathrm{bc}$ & $57.7 \pm 0.9 \mathrm{ab}$ & $44.3 \pm 0.3 \mathrm{a}$ & $119.0 \pm 0.6 \mathrm{~b}$ \\
\hline
\end{tabular}

${ }^{\mathrm{z}}$ The plant lines were planted in greenhouse on July $2^{\text {nd }}, 2008$, and the data was investigated from October 25 th to November $15^{\text {th }}$, 2008.

${ }^{\mathrm{y}}$ Mean \pm standard error

${ }^{\mathrm{x}}$ Different letters in same column represent significant differences by the Duncan's multiple range test, $\mathrm{P} \leq 0.05$

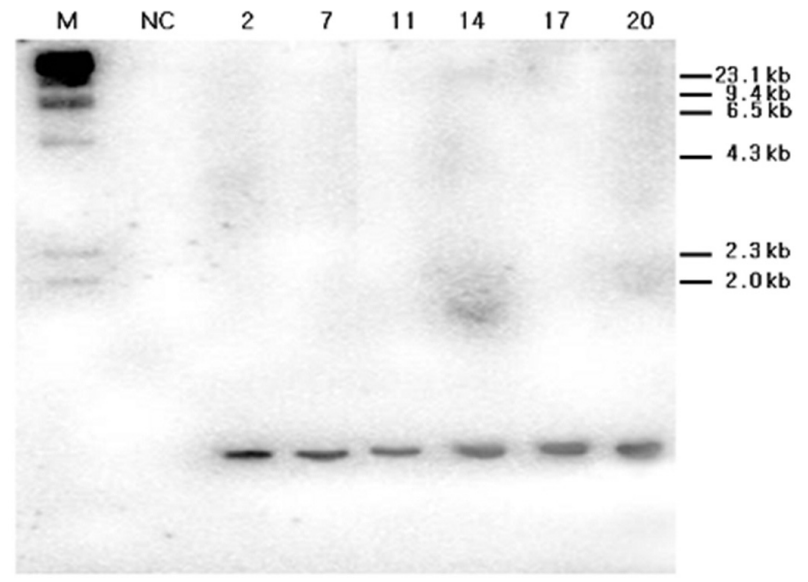

Fig. 4 Southern analysis of MdMSDS2-transgenic chrysanthemum lines showing early-flowering. Total genomic DNA of nontransgenic and transgenic plants was digested with EcoR I. M: Lamda-HindIII digested marker DNA, NC: non-transgenic plant, 2, 7, 11, 14, 17, and 20: transgenic lines

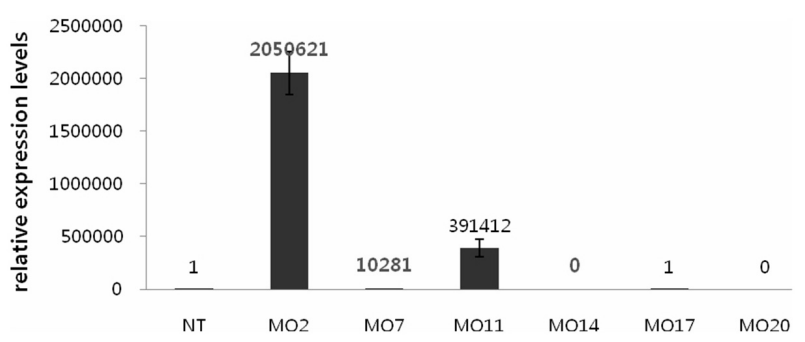

Fig. 5 Real time PCR analysis of MdMSDS2-transgenic chrysanthemum lines showing early-flowering

was reduced by about 13 to $30 \mathrm{~cm}$. This reduction seemed to coincide with the decrease in node number.

Confirmation of introduction and transcription level of transgene in MdMADS2-transgenic lines by Southern and real-time PCR analyses
Southern analysis was done to confirm introduction of $M d-$ MADS2 gene in 6 transgenic lines showing the trait of earlyflowering. All six transgenic lines were confirmed to be integrated MdMADS2 gene (Fig. 4).

Also, real-time PCR analysis was performed to identify transcription level of MdMADS2 gene in them. Relative transcription levels of the transgene in 6 transgenic lines and control are shown in Fig. 5. Whereas the transgene was transcribed in 4 lines (Mo-2, Mo-7, M0-11, and Mo17), it was not in two lines (Mo-14 and Mo-20). Its transcription level in three (Mo2, Mo-7, and Mo17) lines was very high compared to that in control, and Mo-2 line, of which the period to flowering was little shorter than other 5 transgenic lines, exhibited the highest transcription level. Mo-17 line showing reduction of 10 days to flowering on average compared to non-transgenic plant exhibited the same transcription level as control. Flachowsky et al. (2007) also reported that overexpression of BPMADS4 from silver birch induces early-flowering in apple, but no correlation between expression level of transgene and development of in vitro flowers of transgenic clones was found. It is known that flowering of a facultative short-day plant including chrysanthemum cv. Zinba, which flowers from August to midOctober under natural field condition in Korea, is mainly controlled by photoperiod. Though, endogenous factor cannot rule out in controlling of flowering. In other words, it is said that many genes controlling environmental and endogenous factor for flowering need to control it. So, it believed that no correlation between expression level of the transgene and the reduction of days to flowering in MdMADS2-transgenic lines obtained in this study was found, because another gene except MdMADS2 gene is certainly involved for the control of flowering in chrysanthemum cv. Zinba.

In conclusion, MdMADS2 gene from apple could induce an 
early flowering without big change of phenotype in transgenic lines from chrysanthemum cv. 'Zinba'. MdMADS2 transgenic lines obtained in this study will be key fundamental genetic materials for breeding early-flowering chrysanthemum new cultivar.

\section{References}

Amasino RM(1996) Control of flowering time in plants. Curr Opin Genet Dev 6:480-487

An G, Ebert PR, Mitta A, Ha SB (1988) Binary vectors. pp.1-19, In: Plant Molecular Biology Manual, Kluwer Academic Publisher, Belgium.

Aswath CR, Mo SY, Kim SH, Kim DH. (2004) IbMADS4 regulates the vegetative shoot development in transgenic chrysanthemum (Dendranthema grandifora (Ramat.) kitamura). Plant Sci 166: $847-854$

Bernier G (1988) The control of floral evocation and morphogenesis. Annu Rev Plant Physiol Plant Mol Biol 39:175-219

Boase MR, Bradley JM, Borst NK (1998) Genetic transformation mediated Agrobacterium tumefaciens of florists' chrysanthemum (Dendranthema $\times$ grandiflorum) cultivar 'Peach Margaret'. In Vitro Cell Dev Biol-Plant 34:46-51

De Jong J, Mertens MMJ, Rademaker W (1994) Stable expression of the GUS reporter gene in chrysanthemum depends on binary plasmid T-DNA. Plant Cell Rep 14:59-64

Doyle JJ, Dickson EE (1987) Preservation of plant samples for DNA restriction endonuclease analysis. Taxon 36:715-772

Draper J, Scott R, Hamill J (1988) Transformation of dicotyledonous plant cells using the Ti plasmid of Agrobacterium tumefaciens and Pi plasmid of A. rhizogenes. In: Draper J, Scott R, Armitage $\mathrm{P}$, et al., eds. Plant genetic transformation and gene expression: a laboratory manual. p 69-160. Oxford, Egland: Blackwell Scientific Publishers

Flachowsky H, Peil A, Sopanen T, Elo A, Hanke V (2007) Overexpression of BpMADS4 from silver birch (Betula pendula Roth.) induces early-flowering in apple (Malusx domestica Borkh.). Plant Breeding 126:137-145

Foster E, Schneiderman D, Cloutier M, Gleddie S, Robert LS (2002) Modifying the pollen coat protein composition in Brassica. Plant J 31:477-486

Fukai S, De Jong J, Rademaker W (1995) Efficient genetic transformation of chrysanthemum (Dendranthema grandiflorum (Ramat.) Kitamura) using stem segments. Breeding Science 45: 179-184

Han BH, Shu EJ, Lee SY, Shin HK, Lim YP (2007) Selection of non- branching lines introducing Ls-like cDNA into chrysanthemum (Dendranthema grandiflorum (Ramat.) Kitamura) "Shuho-no-chikara". Sci Hortic 115:70-75

Han BH, Lee SY,Park BM (2009) Comparison of chrysanthemum cultivars based on direct shoot regeneration rates in tissue culture. Kor J Plant Biotechnol 36:275-280

Han BH, Yae BW, Yi SY, Lee SY, Shin HK (2003) Introduction of
LEAFY gene to chrysanthemum (Dendranthema $\times$ grandiflorum (Ramat.) Kitamura) 'Shuho-no-chikara' mediated Agrobacterium LBA4404. Kor J Plant Biotechnol 30:335-339

Jack T (2002) Plant development going MADS. Plant Mol Biol 46: 515-520

Khodakovskaya M, Vaňková R (2009) Enhancement of flowering and branching phenotype in chrysanthemum by expression of ipt under the control of a $0.821 \mathrm{~kb}$ fragment of the LEACO1 gene promoter. Plant Cell Rep 28:1351-1362

Ledger SE, Deroles SC, Given NK (1991) Regeneration and agrobacterium mediated transformation of chrysanthemum. Plant Cell Rep 10:195-199

Levy YY, Dean C (1998) The transition to flowering. Plant Cell 10: 1973-1989

Livak KJ, Schmittgen TD (2001) Methods 25:402-408

Lowe JM, Davey MR, Power JB, Blundy KS (1993) A study of some factors affecting Agrobacterium transformation and plant, regeneration of Dendranthema grandiflora Tzvelev, (syn. Chrysanthemum morifolium Ramat.). Plant Cell Tissue and Organ Cult 33:171-180

Murashige T, Skoog F (1962) A revised medium for rapid growth and bioassays with tobacco tissue cultures. Physiol Plant 15: 473-497

Renou JP, Brochard P, Jalouzot R (1993) Recovery of transgenic chrysanthemum (Dendranthema grandiflora Tzvelev) after hygromycin resistance selection. Plant Sci 89:185-197

Rozen, S, Skaletsky H (2000) Primer3 on the WWW for general users and for biologist programmers. Methods Mol. Biol. 132: 365-386

Saini R, Jaiwal S, Jaiwal PK (2003) Stable genetic transformation of Vigna mungo L. Hepper via Agrobacterium tumefaciens. Plant Cell Rep 21:851-859

Sung SK, Yu GH, An G (1999) Characterization of MdMADS2, a member of the $S Q U A M O S A$ subfamily of genes, in apple. Plant Physiol 120:969-978

Takatsu Y, Tomotsune H, Kasumi M, Sakuma F (1998) Differences in adventitious shoot regeneration capacity among Japanese chrysanthemum (Dendranthema grandiflorum (Ramat.) Kitamura) cultivars and the improved protocol for Agrobacteriummediated genetic transformation. J Japan Soc Hort Sci 67: 958-964

Theissen G, Kim JT, Saedler H (1996) Classification and phylogeny of the MADS-box gene families in the morphological evolution of eukaryotes. J Mol Evol 43:484-516

Tong Z, Hong B, Yang Y, Li Q (2009) Overexpression of two chrysanthemum $D g D R E B 1$ group genes causing delayed flowering or dwarfism in Arabidopsis. Plant Mol Biol 71:115-129

Urban LA, Sherman JM, Moyer JW, Daub ME (1994) High frequency shoot regeneration and Agrobacterium-mediated transformation of chrysanthemum (Dendranthema grandiflora). Plant Sci. 98, 69-79

Yan Y, Wang Z (2007) Genetic transformation of the medicinal plant Salvia miltiorrhiza by Agrobacterium tumefaciens-mediated method. Plant Cell Tiss Organ Cult 88:175-184

Yanofsky MF (1995) Floral meristem to floral organs: genes con- 
trolling early events in Arabidopsis flower development. Annu Rev Plant Physiol 46:167-188

Zou X, Li D, Luo X, Luo K, Pei Y (2008) An improved procedure for Agrobacterium-mediated transformation of trifoliate orange (Poncirus trifoliata L. Raf.) via indirect organogenesis. In Vitro Cell Dev Biol-Plant 44:169-177 